DOI https://doi.org/10.18551/rjoas.2018-08.59

\title{
THE CORRELATION MATRIX AMONG VEGETATIVE GROWTH FACTORS OF CANDLENUT PLANTS (REUTEALIS TRISPERMA (BLANCO) AIRY SHAW) IN PRODUCING VEGETABLE OIL FUELS
}

\author{
Santoso Budi* \\ Indonesian Sweetener and Fiber Crop Research Institute, Indonesia \\ Soemarno \\ Faculty of Agriculture, University of Brawijaya, Indonesia \\ *E-mail: b santoso111@yahoo.com
}

\begin{abstract}
Plant height, stem diameter, number of branches and wide canopy are vegetative characters that have strong correlation with the yield of Candlenut (Reutealis trisperma Blanco Airy Shaw). Candlenut is one of the most potential plant that produces biofuel. Biofuel made of Candlenut oil is not only a renewable fuel but it is also environment-friendly fuel. Thus, candlenut oil fuel is considered as sustainable energy. Unlike fossil fuel, candlenut oil does not contain harmful material such as phosphor and heavy metal. In addition, its ability to absorb $\mathrm{CO}_{2}$ and produce $\mathrm{O}_{2}$ at relatively huge amount makes it beneficial to reduce the green house effect that causes global climate changes. This research was conducted in 2015 in Kali Pare experimental garden, Research Institute for Sweetner and Fibre Crops, Malang, Located at $350 \mathrm{~m}$ above sea level with average rainfall $1500 \mathrm{~mm}$ per year and Mediteranian soil type. A Randomized BlockDesign with four replications was employed in this experiment. The treatment consisted of 3 kinds of planting materials, namely cuttings, grafting cuttings and grafting seedlings from seeds. Seedling was a planting space at the dimension of $5 \mathrm{~m} \times 5 \mathrm{~m}$ in the garden. The total plant population used in this study was 300 trees. The purpose of this research was to obtain the index of the correlation matrix among the vegetative growth factors of Candlenut which included the planting cuttings, grafting cuttings and grafting seedlings from seeds. In addition, this study also attempted to obtain a high compatibility index on the material connection process for planting. The objective of this research was to assess the correlation matrix index among vegetative growth characters from different planting materials, namely planting cuttings, grafting cuttings and grafting seedlings. In addition, this research also investigated the best compatibility index and the fastest generative productive age. The Result of this experiment showed that the correlation matrix among vegetative growth characters involved the plant height, stem diameter, number of branches and wide canopy of the Candlenut. The correlation between high vegetative growth of plants (X1) and the stem diameter (X2) was found at the value of $r=0.83^{* *}$, which indicates a significant correlation; The correlation between the stem diameter of vegetative growth (X2) and the number of branches (X3) was found at $r=0.76^{* *}$, which also implies a significant correlation; The correlation between high vegetative growth of plants $(X 1)$ and the number of branches (X3) shows $r=0.68$ *, at a significant correlation; The correlation between the high vegetative growth of plants $(X 1)$ and canopy width $(X 4)$ and the correlation between stem diameter of vegetative growth (X2) and canopy width (X4), each provided value $r=0.630 .69 r={ }^{*}$ and * which shows significant correlation among the variables; The correlation between the amount of vegetative growth of the branch (X3) and canopy width (X4) gives a value of $r=0.49 \mathrm{tn}$, which indicates an insignificant correlation; Whilst, the correlation between the vegetative growth and diameter of the rootstock and the diameter of the trunk obtained a value of $R^{2}=91,53 \%$, which means that redirect cuttings Candlenut is compatible to use.
\end{abstract}

\section{KEY WORDS}

Reutealis trisperma, candlenut, Aleurites Moluccana, biofuels. 
Candlenut plants which are propagated using the true seed are generally more variable than those which are grown out of their vegetative parts (Luntungan et al., 2009). This is due to segregation phenomena that occur during the seed multiplication. Pranowo and Rusli (2012) stated that the grafted plants showed slower growth than the seedling plants although the former posed bigger stem diameters than the later ones. According to Cholid et al. (2015), plant growth in the high-yield plant grafting which is relatively low compared to the plants from seed but it has the size of the diameter of the rod. Almost similar statements were made by Rai (2004) stating that the plants derived from the grafting, their rate of growth seems to experience delay compared to the planting material of the plants derived from the seed. It is further expressed that the process of flowering goes more quickly for plants that grow from grafting.

Candlenut plants produce fuel vegetable oil biofuel/diesel that is environmentally friendly. When the candlenut fuel is used to fuel diesel engine, the exhaust smoke appears to be almost non-existent, because it contains free or low fatty acids (Herman and d. Pranowo, 2011). Furthermore, candlenut vegetable oil also contains no phosphorus or heavy metals which are often found in fossil-based fuel. The candlenut fuel is included into the renewable and alternative fuel that has renewable nature (updated) and sustainable development (ongoing). Another advantage of candlenut is its ability to absorb $\mathrm{CO}_{2}$ and provide much $\mathrm{O}_{2}$ which reduce the impact of global warming caused by climate change.

The Government has been working to find plants that can be used to produce vegetable oil fuel. It is expected that in the next 25 years people will not have to experience difficulties in producing fuel for transportation and industry. According to Syafarudin and Wahyudi (2012) it is estimated that the fossil-based fuel will run out soon. According to Pranowo et al., 2015-growing plants that produce fuel vegetable oil such as Jatropha (Jatropha curcas I.), Sterculia (Sterculia foetida) and Bintaro (Cerbera manghas), Yamplung (Calophyllum inophyllum I.), Kosambi (Schlechera oleosa) and Pongamia (Pongamia pinnata) does not contribute much amount of oil since the oil level of those plants ranges only for $10-30 \%$. Whereas, candlenut oil deposits as much as $51.34 \%$ of oil. The generative growth process of the plant begins from the formation of flowers. The candlenut flowers then grow to be small fruit which usually happens in June and August during the dry season (Ajijah et al., 2009). The candlenut plants start to flower around the fifth year or at age of 55.5 years. However, the obstacles faced by candlenut oil plants when they are ready to flower is their leaves that start to fall down and emerge new shoots that spring and form a flower stalk before forming the fruit. The amount of the oil production of candlenut plants which flower after age of $\geq 5$ years reaches up to 8-10 tons/ha/year (Syakir et al., 2000).

Presently, Indonesia has started to using fuel made of vegetable oil/biofuel from Palm oil biosolar or in order to meet the needs of consumers. The Government of Indonesia has already published a Regulation No. 5/2006 regarding National energy policy and the Impres Number I/2006 on the provision and utilization of vegetable oil fuel (Hasnam, 2009).

The purpose of this research was to obtain the index of the correlation matrix among the vegetative growth factors of candlenut plants including the planting cuttings, grafting cuttings and grafting seedlings from seeds. In addition, this research was also intended to obtain a high compatibility index on the connection material process for planting.

\section{MATERIALS AND METHODS OF RESEARCH}

The research was conducted in 2015 in Kali Pare experimental garden, Research Institute for Sweetner and Fibre Crops, Malang, Located at $350 \mathrm{~m}$ above sea level with average rainfall $1500 \mathrm{~mm}$ per year and Mediteranian soil type. A randomized BlockDesign with four replications was administered in this experiment. Each treatment consisted of 3 kinds of planting materials, namely cuttings, grafting cuttings and grafting seedlings from seeds. Seedling was done in a space planting with dimension of $5 \mathrm{~m} \times 5 \mathrm{~m}$ in the garden and total plant population of 300 trees.

Planting materials used in treatment were the candlenut varieties 1 that were grown from a). Dial side cuttings; b). grafting cuttings, and c). Seedlings from seeds. The observed 
parameters included the height of the plant, stem diameter, number of branches and the width of the canopy at which were measured when candlenut plants reached age of 18 months in the field. Each treatment was observed for 20 times=n.

The formula of correlational coefficient (Sastrosupadi, 2003):

$$
\mathrm{r} 12=\frac{\sum x y-\sum x \cdot \Sigma y / n}{\sqrt{\left(\left(\sum x^{2}-\frac{(\Sigma x)^{2}}{n}\right)\left(\Sigma y^{2}-\frac{(\Sigma y)^{2}}{n}\right)\right)}}
$$

Where: $\mathrm{N}=$ The number of the observed treatment; $\mathrm{X}=$ The parameters of the vegetative growth (height, diameter, the number of branch and canopy width (horizontal axis); $Y=$ The results of the vegetative growth, height, diameter, number of branches and canopy width (vertical axis); $\mathrm{R}=$ The correlation coefficient; $\mathrm{R}^{2}=$ coefficient of determination.

Table 1 - Guidelines in categorizing the correlation coefficient

\begin{tabular}{|ll|}
\hline Interval coefficients & The level of the relationship \\
\hline $0.00-0.199$ & Very low \\
\hline $0.20-0.399$ & Low \\
\hline $0.40-0.599$ & medium \\
\hline $0.60-0.799$ & Strong \\
\hline $0.80-1.000$ & Very strong \\
\hline
\end{tabular}

Source: Sugiono, 2007.

\section{RESULTS AND DISCUSSION}

The result of the correlational analysis on the research parameters which included the height, diameter, number of branches and the canopy width of candlenut plants is presented in Table 2.

Table 2 - Correlation matrix on the parameters of vegetative growth factors of candlenut plants

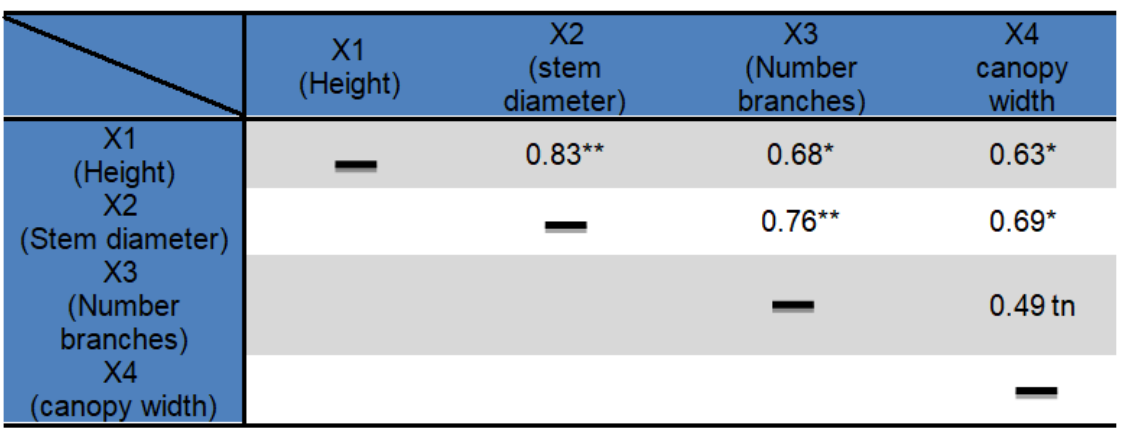

Notes: ${ }^{* *}=$ significant at the extent of $1 \% ;{ }^{*}=$ significant at the extent of $5 \%$; th $=$ not significant.

Table 2 shows that the correlation value $r=0.83^{* *}$ significant of the parameter of plant height $(X 1)$ and the stem diameter $(X 2)$. This correlation value shows that the correlation between those variables is very strong. Both components strongly contribute to the amount of candlenut production. The points show the parameters which are the diameter and height of the plant, which position are spreading closer to the linear lines. The correlation between the height and the growth of the plant stem diameter of candlenut forms a closed quadratic curve (Figure 1).

Figure 1 shows that the correlation between diameter growth parameters $(X 2)$ and the number of branches (X 3 ) of candlenut shows value of 0.76 correlation ${ }^{* *}$ significant. The quadratic curve is presented in Figure 2. The value of the coefficient of determination is at R2 $=$ or $0.7882=78.82 \%$ which means the diversity is at $X 78.82 \%$ under the influence of the $Y$, remainder of $21.18 \%$ outside it. Based on the guidelines in categorizing the value of the correlation coefficient, the value above is considered very strong. 


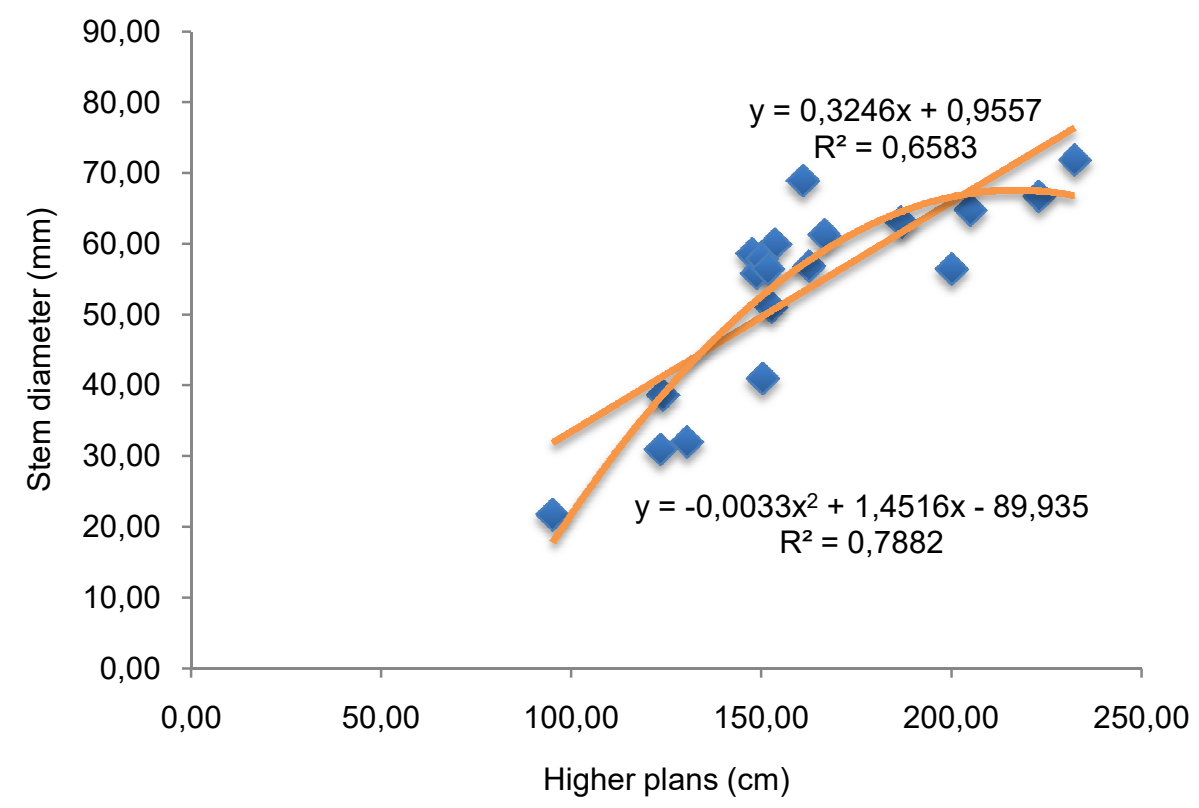

Figure 1 - The correlation between the parameters of the plant's height growth and the stem diameter of candlenut

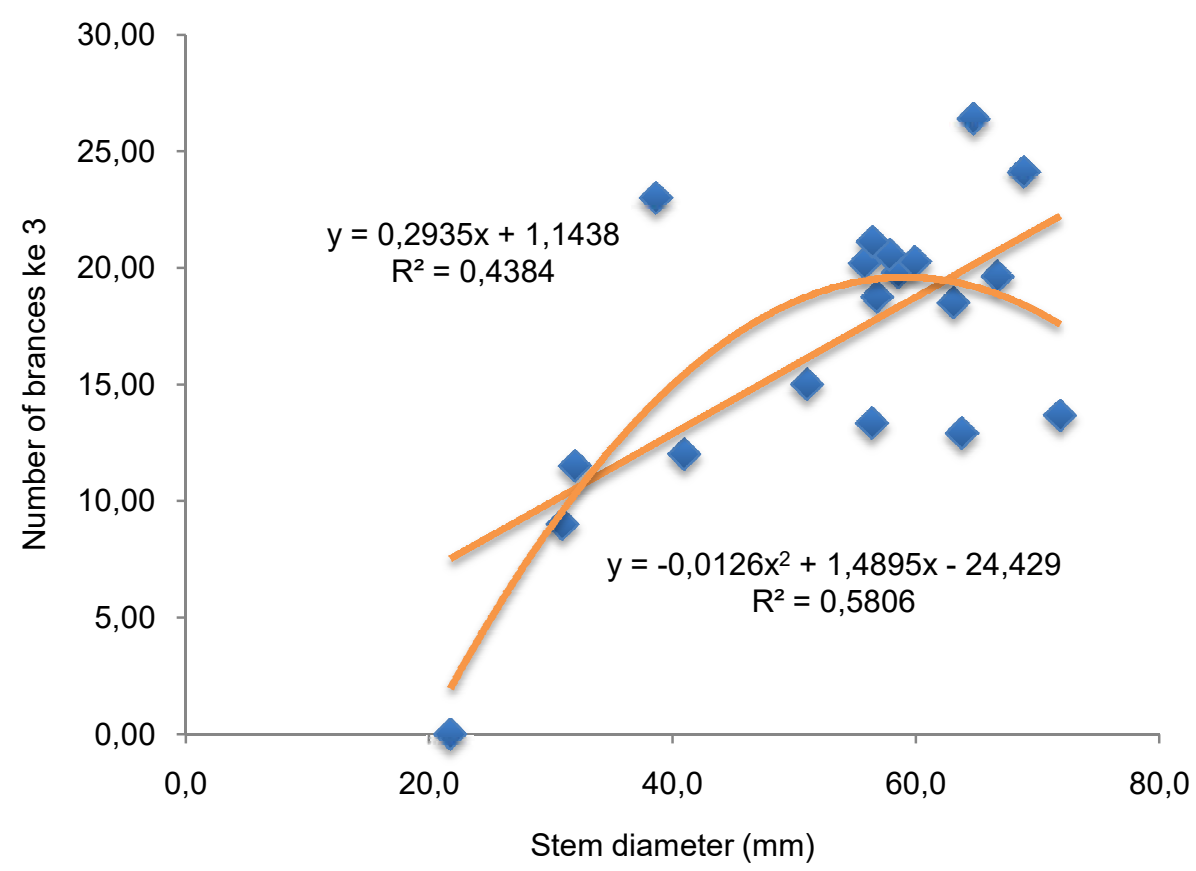

Figure 2 - Correlation between the diameter growth parameters and the amount of candlenut branches

The branch of candlenut plants is where the fruit-producing occurs, allegedly under certain conditions that will result in the production of candlenut.

The correlation between the parameters of the high-growth plants $(X 1)$ and the number of branches $(X 3)$ candlenut provides value $r=0.68$ * real (Tabel1) which indicates strong relationship between the two parameters. The quadratic curve is presented in Figure 3. The value of the coefficient of determination is at $R^{2}=0.4449$ or $R^{2}=44,49 \%$. 


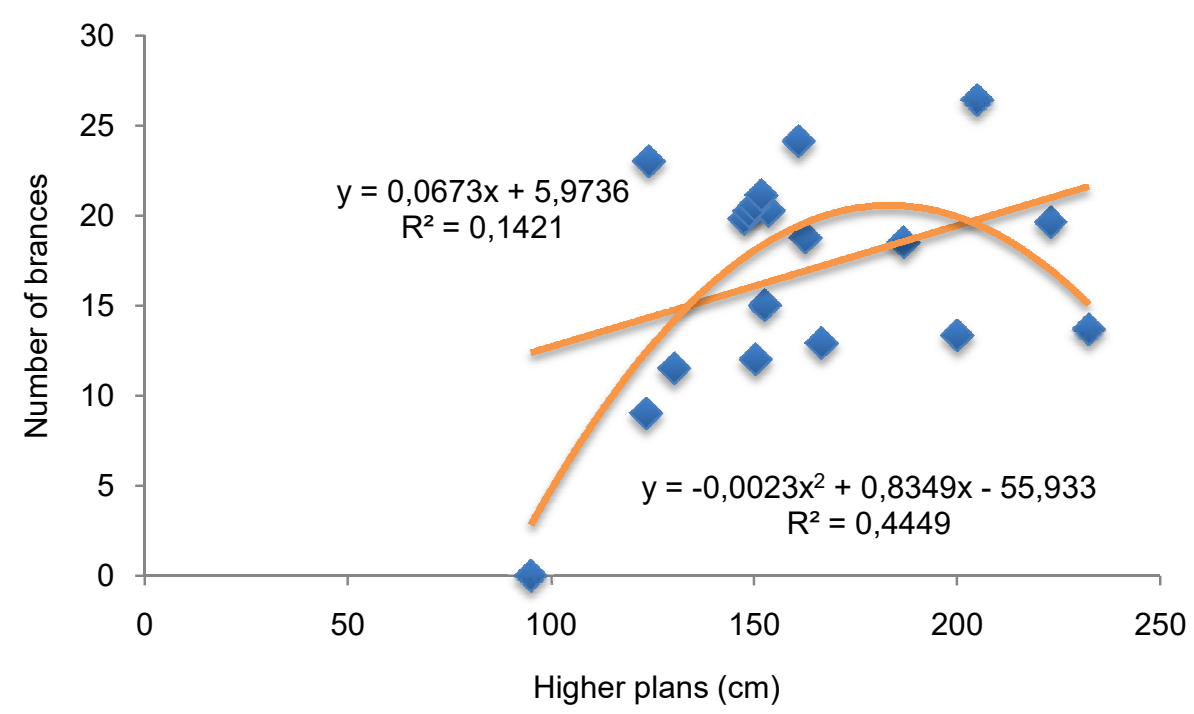

Figure 3 - The correlation between the parameters of the height growth of the plant and the number of branches of the candlenut

For the correlation between the height growth of plants $(X 1)$ and canopy width (X 4) and the parameter $X 2$ diameter growth and canopy width (X 4) (Tabel1), each shows a value of correlation $r=0.63$ * significant and $r=0.69$ * significant. The quadratic curve is presented in Figure 4 and Figure 5 with $R^{2}$ (coefficient determination) respectively are $R^{2}=$ 0.3937 and $R^{2}=0.4776$.

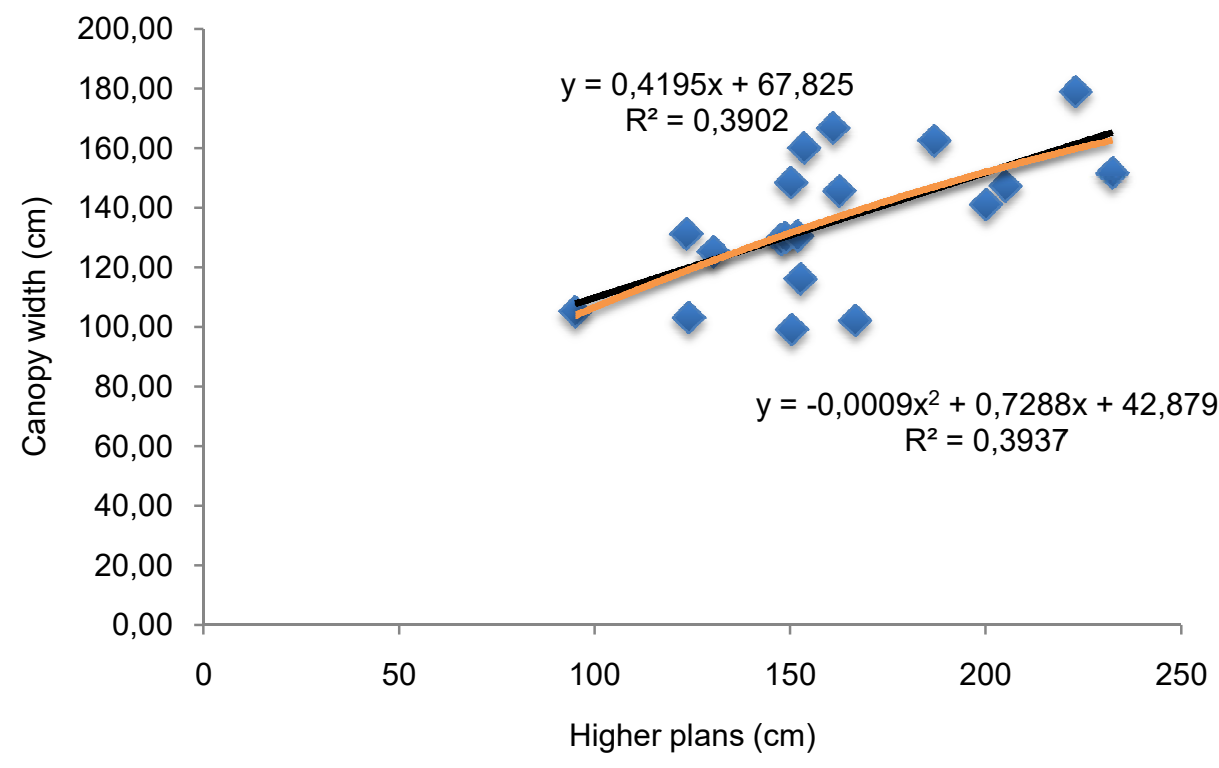

Figure 4 - The correlation between the height and the canopy width of candlenut

The canopy is the part where the photosynthesis occurs, which process produces asymilate as the main ingredient in producing a crop. Allegedly, a real correlation between the value and the produced asimilat is adequate enough to give some effects on the production of Candlenut.

Table 1 shows that the correlation between the parameters of the number of branches (X 3 ) and the canopy width (X 4) shows a correlation value off 0.49 (tn) insignificant. The quadratic curve is presented in Figure 6. 


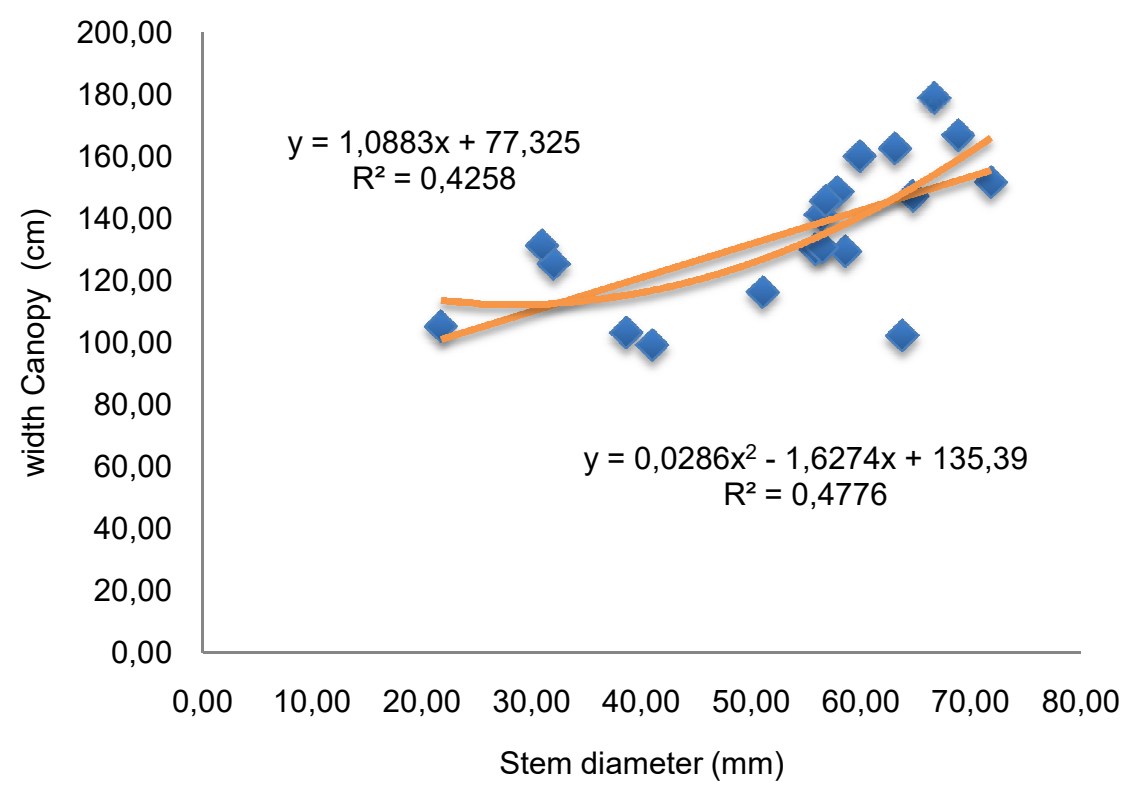

Figure 5 - The correlation between the growth of stem diameter and the canopy width of Candlenut

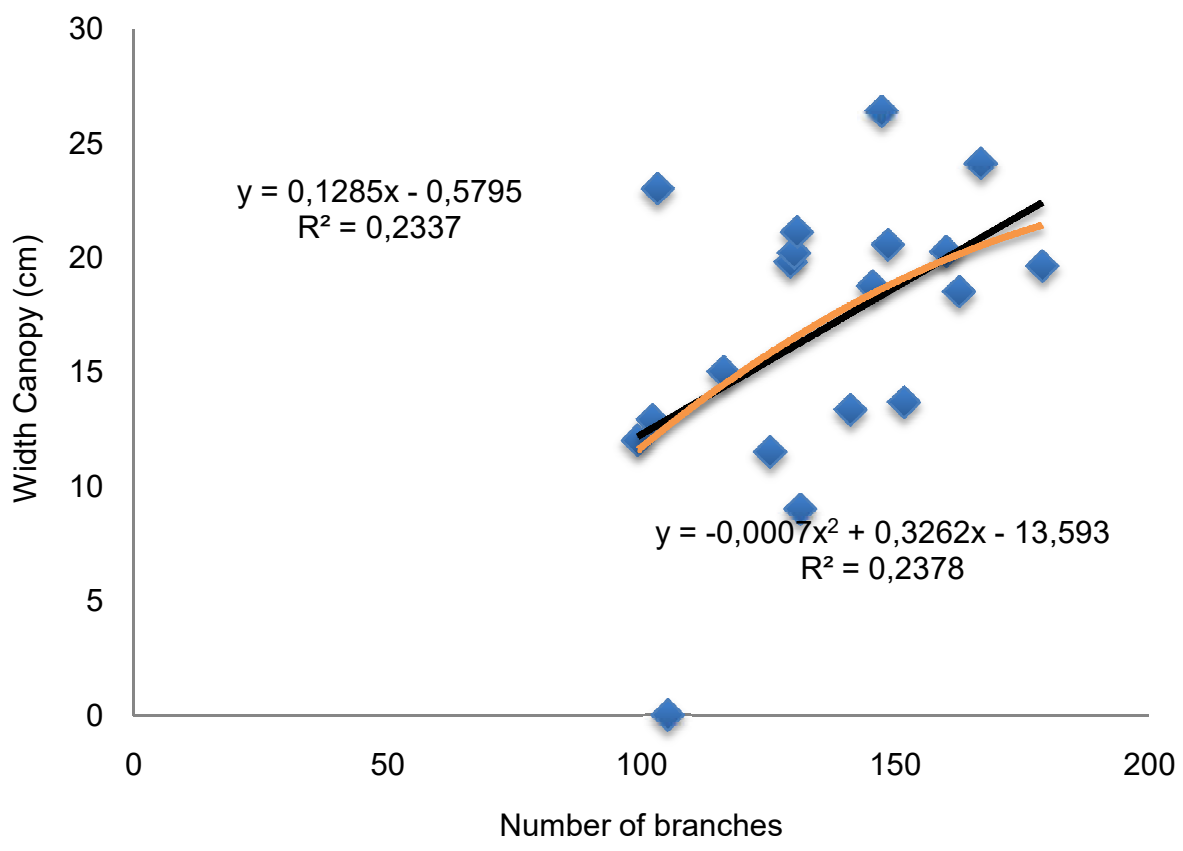

Figure 6 - The correlation between the number of branch and canopy width of candlenut plants

From Figure 6, it is known that some changes increasingly spread far from the linear line which means that the correlation value is only about $r=0.49$ th and value determination of $R^{2}=0.2378$. According to Sugiono (2007), when the value of the correlation lies between $0.200-0.399$ the value can be categorized low as the second parameter of the vegetative growth of candlenut.

Similar result was found in the correlation analysis of the root stock diameter root and the stem diameter. The result of the correlation analysis on the parameters of the stem diameter of top growth (X 1) and stem diameter rootstock $(X 2)$ is presented in Figure 7.

It can be seen from Figure 7 that the value of the correlation parameter of the diameter growth rootstock and the stem diameter is at $R^{2}=0.9153$ or $91.53 \%$ where almost of all the 
distribution changes approach the linear line. This means that $91.53 \%$ of the diversity of $(X 1)$ rootstock growth parameters was $91.53 \%$ influenced by the diversity of the $\mathrm{X} 2$ (stem diameter of top growth paramerter, $8.47 \%$ remainder are outside of it.

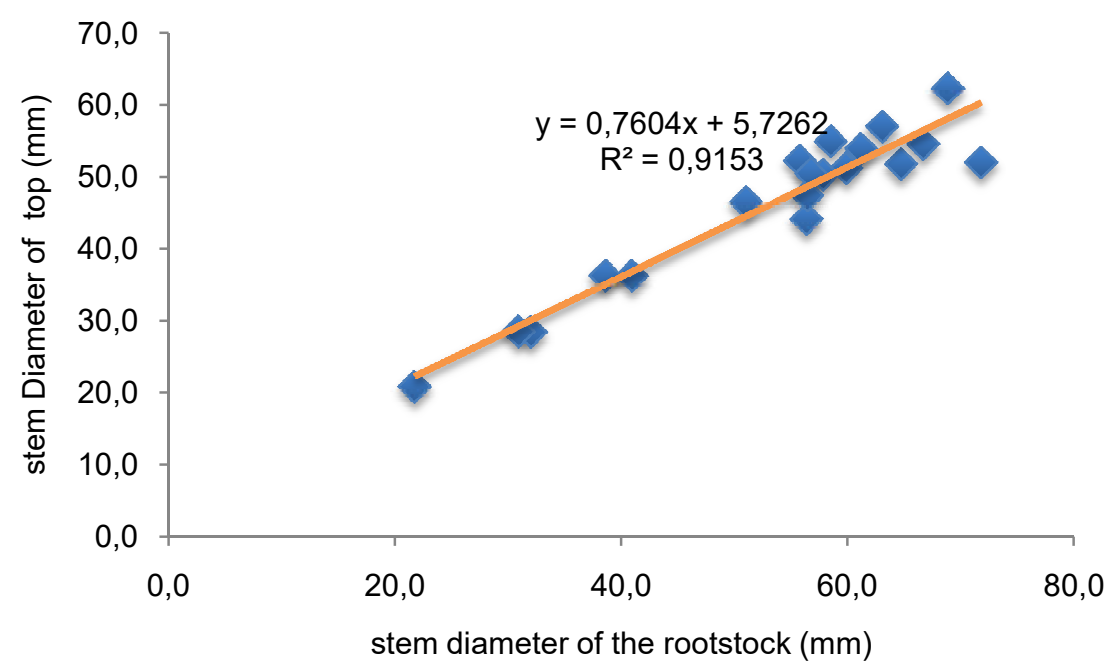

Figure 7 - The correlation between the the diameter of the rootstock and the diameter of the stem top of the candlenut

At $R^{2}=91,53 \%$, the $Y$ variation is influenced by the existence of its relationship with variables $\mathrm{X}$. Therefore, the $91.53 \%$ of variations found in $\mathrm{Y}$ is determined by the index of the fit regression line nearby, namely against the point of observation. The greater the $R^{2}$ means the more the line fit the regression towards the points of observation. Thus, the process of grafting cuttings candlenut has been considered appropriate (accordingly), in which its growth does not suffer any interference.

\section{CONCLUSION}

From the result of this research, conclusions are drawn as follows:

The correlation between the plants' height $(X 1)$ and the stem diameter $(X 2)$ of candlenut plants provide a value $r=0.83^{* *}$ which shows significant influence between those parameters and also indicates that the relationship is very strong.

The correlation between the stem diameter (X 2) and the number of branches (X 3$)$ of candlenut plants shows value $r=0.76^{* *}$ which implies that the influence is significant and the relationship is very strong.

The correlation between the plants' height (X 1) and the number of branches $(X 3)$ of Candlenut plants shows value $r=0.68^{*}$ which indicates the real influence and strong relationship between those parameters.

The correlation between the plants's height and canopy width (X1) and (X 4) and correlation between the stem diameter (X 2) and the canopy width (X 4) of Candlenut plants show that the value were found at $r=0.63^{*}$ and $r=0.69$ *both show significant influence and strong relationship between the parameters.

The correlation between the number of branches (X 3$)$ and canopy width $(X 4)$ of Candlenut plants shows value $r=0.49$ (tn) insignificant, which means that the influence is not significant and the relationship between those parameters are considered medium.

The correlation between the stem diameter growth bottom (X 1) and stem diameter of top(X2) of the candlenut grafting cuttings shows value $R^{2}=91,53 \%$. Grafting cuttings is considered compatible for candlenut plants. 


\section{REFERENCES}

1. Ajijah, N., I.N.A. Wicaksono, Syafarudin. 2009. Bunga rampai kemiri sunan unreal and penghasil biodesel, solusi masalah energy masa depan. Karakterisasi Morfologi Bunga. Balai Penelitian Tanaman Rempah dan Aneka Tanaman Industri. Hal 45-54.

2. Cholid, M., H. Setiana, B. Santoso \& R.D. Purwati. 2015. Perakitan Varietas Unggul dan Teknologi Budidaya Tanaman Kemiri Sunan. Unpublished Research Report. Balai Penelitian Tanaman Pemanis dan Serat Malang. Hal 1-28.

3. Hasnam. 2009. Tangapan Atas Implementasi Program Pengembangan Jarak Pagar Sebagai Sumber Energi Alternatif. Proceedings. Akselarasi Inovasi Teknologi Jarak Pagar Menuju Kemandirian Energi.

4. Herman, M. \& D. Pranowo. 2011. Karakteristik buah dan minyak kemiri minyak (Reutealis trisperma (Blanco) Airy Shaw) Populasi Majalengka dan Garut. Buletin RISTRI, 2(1): 21-27.

5. Pranowo, D., M. Herman, Syafaruddin. 2015. Potensi pengembangan kemiri sunan (Reutealis trisperma (Blanco) Airy Shaw) di lahan terdegradasi. Journal Perspektif Review Penelitian Tanaman Industri,Vol. 14 No.2. Hal 73-150.

6. Luntungan H.T., D. Herman, M.E.A. Hadad. 2009. Bahan Tanam dan Budidaya Kemiri Sunan Penghasil Biodesel, Bunga Rampai Solusi Masalah Energi Masa Depan. Unit Penerbitan dan Publikasi Balittri. Sukabumi..

7. Rai, M. 2004. Fisiologi Pertumbuhan dan Pembungaan Tanaman Manggis (Garcinia mangostana L.) Asal Biji dan Sambung. Unpublished Graduate Thesis. IPB. Bogor.

8. Sastrosupadi, A. 2003. Penggunaan Regresi, Korelasi Koefisien Lintas dan Analisis Lintas Untuk Penelitian Bidang Pertanian. Penerbit Bayu Media.

9. Syafarudin \& A. Wahyudi. 2012. Potensi varietas unggul kemiri sunan sebagai sumber energy bahan bakar nabati. Perspektif, 11(1): 59-67.

10. Syakir, M., M. Herman, D. Pranowo, H.M. Hasibuan. 2015. Budidaya dan Agribisnis Kemiri Sunan Sumber Bahan Bakar Nabati. IAARD Press. Jakarta.

11. Sugiono. 2007. Statistika Untuk Penelitian. Penerbit Alfabeta Bandung. 